\title{
Statyba
}

\section{THE ESTIMATION PROBLEMS OF THE FIRE HAZARD FOR VERTICALLY ORIENTED BUILDING PRODUCTS}

\section{A. Nyderis MSc (fire safety and engineering)}

To cite this article: A. Nyderis MSc (fire safety and engineering) (1999) THE ESTIMATION PROBLEMS OF THE FIRE HAZARD FOR VERTICALLY ORIENTED BUILDING PRODUCTS, Statyba, 5:1, 74-78, DOI: 10.1080/13921525.1999.10531436

To link to this article: https://doi.org/10.1080/13921525.1999.10531436

曲 Published online: 26 Jul 2012.

Submit your article to this journal

III Article views: 51 


\section{VERTIKALIAI ORIENTUOTU STATYBINIŲ GAMINIŲ GAISRINIO PAVOJINGUMO IVERTINIMO PROBLEMOS}

\section{A. Nyderis}

\section{Ivadas}

Europos Ekonominès Komisijos III generalinio direktorato gamybos sektoriaus statybos skyriuje parengta ir $1988 \mathrm{~m}$. gruodžio $21 \mathrm{~d}$. patvirtinta privalomojo pobūdžio vadinamojo naujojo požiūrio (new approach) direktyva "Dèl valstybių nariu statybos produktų teisinių ir administracinių nuostatų suvienodinimo (89/106/EEC)" [1]. Remiantis šiuo dokumentu parengti 6 aiškinamieji dokumentai, kurių antroji dalis apima gaisrinès saugos statyboje nagrinejjima. Europos Sajungos (ES) šalys pagal šią direktyvą parenge nacionalinius statybos istatymus ir taisykles. Direktyvoje yra nurodyta, kaip turi būti suprojektuoti statiniai, kad:

- kilus gaisrui tam tikrą laiko tarpa laikančiosios konstrukcijos galètu išlaikyti jas veikusias ir papildomai susidariusias apkrovas;

- būtų ribojamas ugnies ir dūmų plitimas statinyje;

- būtų ribojamas gaisro plitimas i gretimus statinius;

- pastate esantys žmonès galètu saugiai iš jo išeiti ar bütų galima juos išgelbéti kitomis priemonèmis;

- pradètų veikti gaisro aptikimo, žmonių ispèjimo ir gaisro gesinimo sistemos;

- gelbètojai galètų saugiai dirbti.

Be statybinių konstrukcijų atsparumo ugniai, didelis demesys yra skiriamas ugnies plitimui statybinių gaminių paviršiais. Tačiau šis klausimas vertas išsamesnio nagrinejjimo, jis dar nèra gerai ištirtas ir reglamentuotas.

\section{Kietụjų medžiagų degimo procesas}

Dauguma statybiniu medžiagu ir gaminiu yra kieto agregatinio būvio. Darbe [2] nagrinejjamas šių medžiagų degimo procesas. Kietųjų medžiagu degimas parodytas 1 pav.

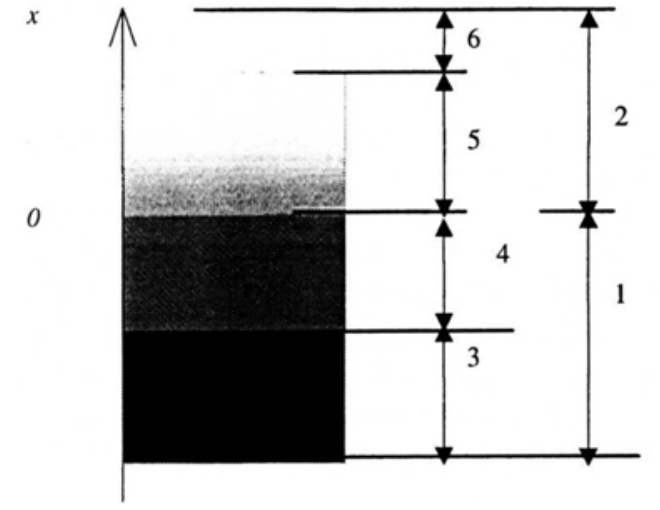

1 pav. Kietosios medžiagos degimo modelis: 1 - kondensuotas agregatinis būvis; 2 - duju fazè; 3 - kieto agregatinio būvio zona; 4 - reakcijos zona garų kondensacijos fazeje; 5 - reakcijos zona duju fazeje; 6 - dujiniai degimo produktai

Fig 1. The model of combustion of the solid material: 1 condensation phase; 2 - gas-phase; 3 - non-reaction zone in the condensation phase; 4 - reaction zone in the vapourcondensation phase; 5 - reaction zone in gas-phase; 6 gaseous combustion products

Reakcijos zonos šiluma padidina kietosios medžiagos temperatūrą iki tokios, kai medžiagoje pradeda vykti fazinio virsmo arba kiti sudetingi cheminiai procesai. Jie gali būti tiek egzoterminiai, tiek ir endoterminiai priklausomai nuo proceso atsiradimo laiko ar jo prigimties. Pakilus temperatūrai, kinta medžiagos büvis. Pavyzdžiui, išsiskyrusios dujos oksiduojasi reakcijos zonoje ir galiausiai virsta degimo produktais.

Kadangi kietosios medžiagos yra skirtingos cheminès sudeties, skiriasi ir jų gazifikacijos (pirolizès) greitis. Gazifikacijos greitis, be abejo, turi itakos kietosios medžiagos degimo greičiui. Vienkomponentès medžiagos kondensuotos fazès gazifikacijos procesas, vykstantis pagal pirmojo laipsnio reakcija yra išreiškiamas taip (kada $x=0$ ):

$$
\Re_{l}(s) \rightarrow \Re_{l}(g),
$$

$\Re_{l}$ - sublimacijos komponento simbolis, $s$ ir $g$ simboliai reiškia kietają $(s)$ ir dujų $(g)$ fazes. Jeigu 
aktyvuoty kompleksų, esančių ploto vienete ir atitinkančių sublimacijos procesą skaičių, pažymèsime $\gamma$, o $\tau$ bus kompleksu sublimacijos laikas, per kurị šie kompleksai palieka paviršiaus ploto vienetą per sekundę, tai masès degimo greiti galima aprašyti taip:

$$
m=W_{l} \gamma / \tau,
$$

čia $W_{I}$ - vieno komponento molekuliné masé.

Pagal cheminès reakcijos absoliučiojo greičio teoriją dydis $\gamma$ yra susijęs su vieno komponento moliy skaičiumi ploto vienete $\gamma_{1}$, o pusiausvyros sąlyga yra: $\gamma \gamma_{I}=K_{\gamma} . K_{\gamma}$ galima traktuoti kaip kompleksu susidarymo proceso pusiausvyros konstantą. Tuomet gausime tokią galutinę išraišką:

$$
m=W_{1} \gamma_{1} K_{\gamma} / \tau
$$

Pasinaudojus chemijos reakcijos idealiųjų duju aplinkoje sąlygu ịvertinimu, kada pusiausvyros konstanta $K_{\gamma}$ prilyginama $K_{c}$, kur ji yra tenkančiu paviršiaus vienetui statistinių sumų santykis, masès degimo greitị galima apskaičiuoti taip:

$$
m=W_{1} \gamma_{1}\left(K T_{i} / h\right)\left(q / q_{1}\right) e^{-\left(E / R T_{i}\right)}
$$

čia $K$ - Bolcmano konstanta; $R$ - universalioji duju konstanta; $h$ - Planko konstanta; $E$ - sublimacijos proceso aktyvacijos energija; $T_{i}$ - paviršiaus temperatūra (kai $x=0$ ); $q_{1}$ - vieno komponento statistinè suma, tenkanti paviršiaus ploto vienetui, kai neịvertintas būklès daugiklis; $q$ - aktyvuoto komplekso statistinè suma, neįvertinant laisvès lygio, atitinkančio pernešimo judèjimą reakcijos kryptimi.

Procesas, nurodytas formulëje (1), gali būti ir grịžtamasis tada, kada kietosios medžiagos molekulès grižza ị skystają ar net kondensuojasi i kietają fazę.

Tokie procesai priklausomai nuo aplinkos temperatūros gali vykti su oro deguonimi, kada medžiagos dega arba smilksta, ir be jo, kada ivyksta medžiagos terminè destrukcija - pirolizè. Darbe [3] pateiktas toks kietujų medžiagu pirolizès matematinis modelis:

$$
\begin{gathered}
\partial(\rho H) / \partial t+m " '\left(H_{p y}+H\right)+\partial\left[m^{\prime \prime}\left(H_{G, T}-H_{G, T p}\right)\right] / \\
/ \partial x=(\partial / \partial x)(k[\partial T / \partial x]),
\end{gathered}
$$

čia $m$ "'=- $\partial \rho / \partial t=\partial m$ "' $\partial x \geq 0$ yra medžiagos masès nuostolio greitis tūrio vienete; $H_{p y}$ - pirolizès reakcijos šiluma.

Realiuose gaisruose ypač intensyvūs medžiagu irimo (gazifikacijos) procesai. Nuo šiu procesų vyksmo intensyvumo priklauso išsiskiriančios šilumos kiekis. Degimo šiluma i aplinką perduodama konvekciniu, spinduliavimo ir kitais būdais. Šie šilumos perdavimo būdai yra svarbūs modeliuojant gaisro sąlygas, o kartu turi tiesioginès ịtakos statybinių gaminių gaisriniam pavojingumui jvertinti. Yra apskaičiuota, kokia vieno ar kito šilumos perdavimo mechanizmo dalis gaisro atveju tenka statybinèms konstrukcijoms. Tačiau didžiausia šilumos dalis perduodama spinduliavimu (>50\%). Šị būdą lengviausia modeliuoti kuriant laboratorinius bandymus. Ši procesą aprašant Stefano-Bolcmano dèsniu [4] šilumos pusiausvyros sąlyga išreiškiama tokia lygtimi:

$$
E / A=E_{o}=c_{o}(T / 100)^{4},
$$

čia $E$ - kūno spinduliavimo energija; $A$ - kūno geba sugerti energiją esant tam tikrai temperatūrai; $E_{o}-$ absoliučiai juodo kūno spinduliavimo energija; $c_{o}-$ absoliučiai juodo kūno spinduliavimo koeficientas; $T$ spinduliuojančio kūno temperatūra.

Realių kūny̨ spinduliavimo energija aprašoma tokia lygtimi [4]:

$$
E=c(T / 100)^{4},
$$

čia $c$ - pilko kūno spinduliavimo koeficientas.

Šilumos perdavimas konvekcijos būdu gaisro metu yra nestacionarus, todel tokius procesus modeliuoti laboratorinèmis sąlygomis kol kas nèra techninių galimybių.

\section{Vertikaliai orientuotų gaminių gaisrinių bandymy problemos}

Gaisriniais bandymais galima nustatyti statybinių medžiagų degumo grupę. Darbe nurodytu [5] metodu galima nustatyti statybinių gaminių gebejjimą užsidegti nuo išorinio šilumos spinduliavimo šaltinio, o darbe [6] nurodytais kriterijais ji ivertinti. Tokiais atvejais yra išbandomi mažų matmeny gaminiai (160 $\mathrm{mm} x$ $160 \mathrm{~mm} \times 70 \mathrm{~mm}$ ), kurie bandymo metu yra veikiami kalibruoto šilumos spinduliavimo srauto.

Darbe [7] nurodytu metodu galima nustatyti sunkiai degių arba degiuju medžiagu liepsnos plitimo indeksą ( $L P I)$. Taip yra išbandomi mažų matmenų $(320 \mathrm{~mm} \times 140 \mathrm{~mm} \times 20 \mathrm{~mm}$ ) gaminiai. Medžiagos gali būti tokios, kuriu paviršiumi liepsna neplinta $(L P I=0)$, kurių paviršiumi liepsna plinta lètai $(L P I<20)$ ir kurių paviršiumi liepsna plinta greitai $(L P I \geq 20)$. 
Kadangi mažų matmenų bandiniai nenusako statybos konstrukcijų kitimo pobūdžio realių gaisrų metu, todèl tikslinga trumpai apžvelgti îvairiose pasaulio šalyse atliekamus statybiniu konstrukciju fragmenty tyrimus ir bandymus. Darbuose [8] ir [9] pateikiama îvairiose šalyse atliktų gaisriniu bandymy analize ir vertikalios atitvaros gaisrinio pavojingumo ¡vertinimo bandymais teorinès prielaidos, panaudojant statybinés konstrukcijos fragmentą $(2,4 m \times 2,0 \mathrm{~m})$, išorini šilumos spinduliavimo šaltini $(0,8 m \times 0,7 \mathrm{~m})$ ir duju degikli. Darbe [10] buvo atlikti tyrimai su $2,4 m \times 1,2 m$ matmeny bandiniais, veikiant juos šilumos spinduliavimo šaltiniu $(3,2 m \times 0,9 m)$ ir liepsnos šaltiniu. Bandiniuose įrengtais šilumos srauto matavimo davikliais ir termoelementais buvo nustatytos atitinkamos šilumos spinduliavimo ir temperatūros skaitmeninès reikšmès tam tikru laikotarpiu. Kitame darbe [11] pateiktas liepsnos plitimo modelis vertikalia konstrukcija, kai ji yra veikiama šilumos spinduliavimo šaltinio $(3,6 m \times 2,7 \mathrm{~m})$. Temperatūros matavimais buvo nustatytos bandinio paviršiaus $(2,4 m \times 0,61 \mathrm{~m})$ temperatūros esant skirtingiems šilumos spinduliavimo srauty tankiams. Darbe [12] yra aprašytas liepsnos plitimas vertikalia konstrukcija kambario kampe. Čia pateikiamas matematinis modelis liepsnos aukščiui nustatyti priklausomai nuo skirtingụ parametrų. Darbe [13] nagrinèjami vertikalių pavirši ì ikaitimo ir užsiliepsnojimo matematiniai modeliai ir palyginti apskaičiavimy ir bandymy rezultatai. Pažymima, jog bandymu ir apskaičiavimo rezultatai labai gerai sutampa. Publikacijoje [14] nagrinejjamas liepsnos plitimas vertikaliais mediniais paviršiais $(2,4 \mathrm{~m} \times 1,2 \mathrm{~m})$, naudojant dujų degikli $(300 \mathrm{~kW})$. Joje pateikti bandymu rezultatai ir nustatytas tinkamiausias šio proceso matematinis modelis.

Liepsnos plitimo statybinemis konstrukcijomis ivertinimo svarba akcentuojama ir [15] darbe. Pagrindines organizacijos, kurios plètoja šios srities metodinę bazę, yra IMO (Tarptautinè jūry organizacija), ASTM (Amerikos medžiagų bandymų asociacija) ir ISO (Tarptautiné standartizacijos organizacija).

Svarbi publikacija [16], kurioje nagrinejjama ES šalyse numatomo taikyti vadinamojo atskiro degančio daikto SBI (single burning item) bandymo metodo idèja.

\section{Vertikaliai orientuotu gaminių gaisrinių tyrimų plètra}

Publikacijose [8-14] nagrinejjami vertikalių konstrukcijų degimo procesai statinio viduje. Paskutini dvidešimtmetị pasaulio šalių mokslininkai didelị dėmesị skyrè îvairioms gaisro sąlygoms modeliuoti statinio viduje. Tačiau nebuvo kreipiamas dèmesys $\mathfrak{i}$ išorès fasadu kitimo pobūdi gaisro metu. Liūdna gaisrų patirtis parodè, kad statinių išorès apdaila taip pat turi ịtakos gaisrų bei degimo produktų išplitimui ir tai yra viena iš priežasčių, dèl kurių būta daug aukụ gaisruose.

2 pav. pateikti juairių statybinių medžiagų gaisrinių bandymų bei tų duomenų vidutinių reikšmių rezultatai. Bandymai buvo atlikti Gaisrinių tyrimų centre 1994-1997 metais.

Skirtingu medžiagu bandymų rezultatai parodè, kad jų užsidegimo laikas priklausomai nuo šilumos srauto tankio yra tam laikui atvirkščiai proporcingas. Vidutiné kreivè atitinka svertinių vidutinių rezultaty užsidegimo laiko priklausomybę nuo šilumos srauto tankio ( 2 pav. duomeny pagrindu) išbandant skirtingos cheminės sudéties medžiagas ar atitinkamus kompozitus. Nustatyta eksperimentine priklausomybè, artima logaritminei funkcijai, kurią apskaičiuoti galima pagal toki funkcini modeli:

$$
\tau=a+b \lg q,
$$

čia $\tau$ - užsidegimo laikas, $s ; a$ ir $b$ - koeficientai; $q$ - šilumos srauto tankis, $W / \mathrm{cm}^{2}$.

Skaičiuojant gauta konkreti priklausomybè yra tokia:

$$
\tau=167,64-219,85 \lg q,
$$

o modelio apskaičiavimo paklaida $\left(\sigma_{0}\right)$ yra $7,9 \mathrm{~s}$.

Pagal (9) formulę galima nustatyti konkrečios sudèties statybinių gaminių užsidegimo nuo išorinio šilumos srauto laiką.

Apie statiniu fasady gaisrinio pavojingumo ivertinimo problemas rašoma paskutinių CEN/TC 127 posèdžių dokumentuose [17]. Nuo šių metų gegužès CEN/TC 127 jau sudarytos dvi darbo grupès (adhoc 33 "Fire resistance tests-external wall systems" ir adhoc 34 "Fire resistance tests-facades and curtain walling systems") išoriniu sieny gaisrinių bandymy problemoms spręsti. Grupeje adhoc 34 pradedamos nagrinèti statinių fasadụ pusiau natūraliụ gaisrų problemos [18]. 
Darbe [9] pateikta vertikalios konstrukcijos gaisrinio pavojingumo įvertinimo ideja yra plètojama dèl šių priežasčių:

- šiuo metu nei Europoje, nei tarptautiniu lygiu nèra bendrai pripažinto bandymo metodo;

- naudojami bandymo įrenginiai (elektrinis šilumos spinduliavimo srauto šaltinis, dujų degiklis), mažiausiai teršiantys aplinką;

- bandymo metodas pritaikytas kompleksiškai ịvertinti statybinę konstrukciją.

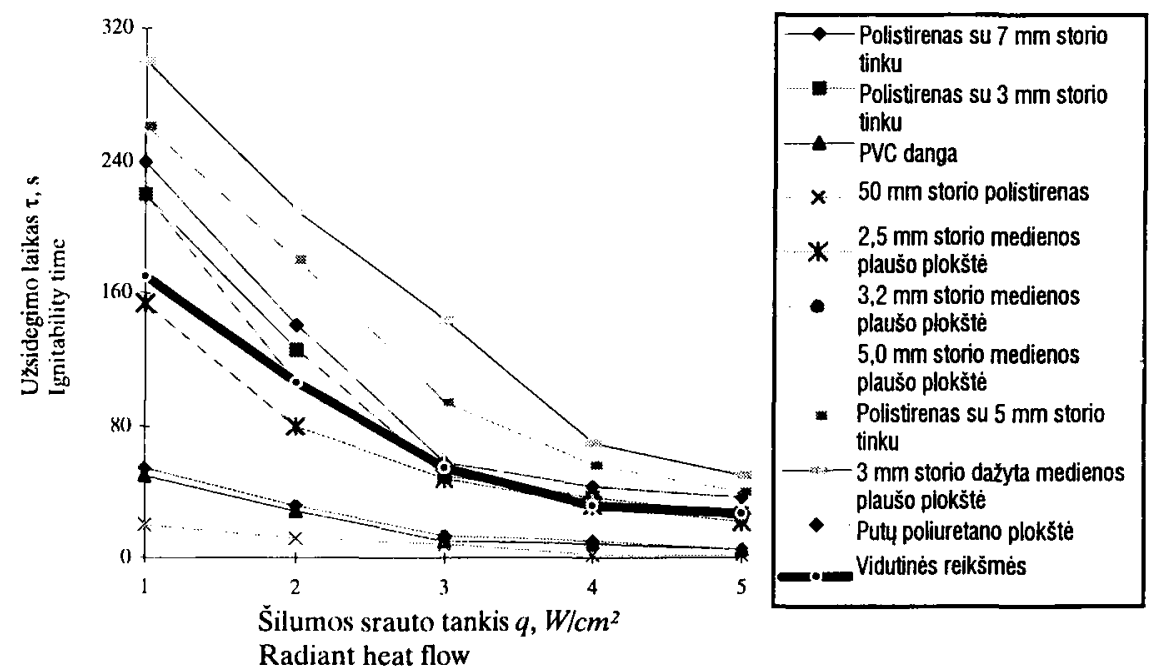

2 pav. Statybiniu medžiagu užsidegimo laiko $(\tau)$ priklausomybè nuo šilumos spinduliavimo srauto $(q)$ dydžio

Fig 2. The dependency of the combustibility time $(\tau)$ of building product from the radiant heat flow $(q)$

Šio bandymo įrengimo bendras vaizdas pateiktas 3 pav. (ji svarbu detaliau paanalizuoti).

Kadangi atstumas tarp šilumos spinduliavimo šaltinio ir konstrukcijos yra kintamas, galima keisti šilumos srauto tanki. Šilumos spinduliavimo šaltinio dydis (1/9 bendro konstrukcijos fragmento ploto) sudaro galimybę galimam savaiminiam liepsnos išplitimui konstrukcijoje. Duju degiklis uždega išsiskyrusius degiuosius garus ir tai yra labai panašu $i$ realụ gaisrą statinio išorèje.

Bandymų rezultatụ ir šios analizès pagrindu planuojama parengti normatyvinį dokumentą vertikalių statybinių konstrukciju gaisriniam pavojingumui ịvertinti.

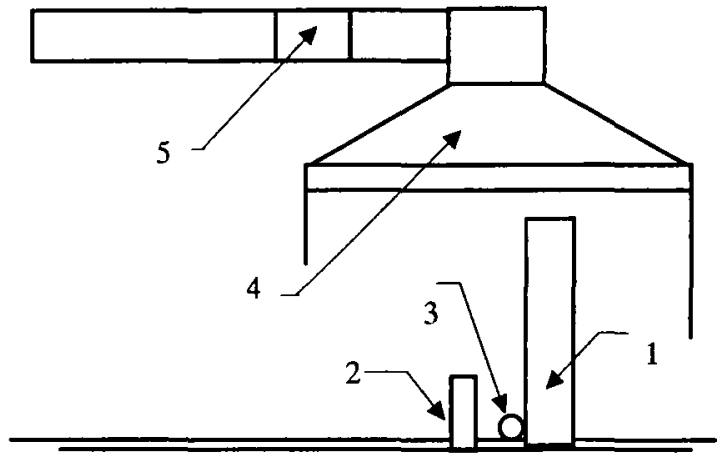

3 pav. Vertikalios statybinès konstrukcijos gaisrinio bandymo schema: 1 - konstrukcijos fragmentas; 2 - šilumos spinduliavimo šaltinis; 3 - dujų degiklis; 4 - ventiliacijos gaubtas; 5 - degimo produkty ir temperatūros daviklių irrengimo vieta

Fig 3. The scheme of the fire test of vertical building construction: 1 - the fragment of construction; 2 - radiant heat source; 3 - gas burner; 4 - ventilation hood; 5 - place of the smoke and temperature measuring system

\section{Išvados ir pasiülymai}

1. Nuolat didejantis gaisrų ir auku gaisruose skaičius, dideli materialiniai nuostoliai verčia tirti gaisro proceso įtaką statybinių gaminių kitimai gaisro metu ir ieškoti būdu šiai ịtakai kiekybiškai aprašyti, kad būtų galima prognozuoti statybiniu gaminių gaisrini pavojingumą. Tam Gaisriniu tyrimy centre yra sukaupta ir apdorota pakankamai patikimy statistiniu bandymų duomenų. Jie leidžia spręsti šią problemą, pasiūlyti naujų bandymų metodikų ir jas pagrįsti.

2. Vertikaliai orientuoty statybiniu gaminiu gaisriniai bandymai ivvairiose pasaulio šalyse vykdomi skirtingai. Kadangi bendro îvertinimo būdo kol kas nèra, šiame darbe, be gaisrinio bandymo idèjos, dar yra siūloma spręsti ir tokius uždavinius:

- detaliai aprašyti bandymų irangą ir kaip ją pagaminti;

- sukurti bandymo metodiką;

- išbandyti ivvairias naudojamas statybines medžiagas, apdoroti ir susisteminti tyrimų duomenis;

- pastaty fasadams naudojamus statybinius gaminius klasifikuoti ir susisteminti pagal gaisrini pavojingumą.

\section{Literatūra}

1. $89 / 106 / E E C$ : Council Directive of 21 December 1988 on the approximation of lows, regulations and administrative provisions of the Member States relating to construction products. Off.Jour. N. 040, 11/02/1989. 80 p.

2. Combustion theory by Forman A. Williams. University of California. Addison-Wesley Publishing Company, Reading, Massachusetts, Palo Alto, London. 615 p. 
3. Yan and G. Holmstedt. CFD Simulation of Upward Flame Spread over Fuel Surface. Fire Safety ScienceProceedings of the Fifth International Symposium. International Association for Fire Safety Science, 1997. P. 345-355.

4. Ю. А. Кошмаров, М. П. Башкирцев. Термодинамика и теплопередача в пожарном деле. М.: ВИПТШ МВД СССР, 1987. $443 \mathrm{c.}$

5. LST ISO 5657:1998 Reagavimo ị ugnị bandymai. Statybiniu gaminiu užsidegimas naudojant šilumos spinduliavimo šaltini / Lietuvos standartizacijos departamentas, 1998. $41 \mathrm{p}$.

6. LST 1533:1988 Statybiniai gaminiai. Užsidegimo îvertinimo rodikliai / Lietuvos standartizacijos departamentas, 1998. 2 p.

7. LST 1532:1998 Gaisriniai bandymai. Liepsnos plitimo indekso nustatymo metodas ir ivertinimas / Lietuvos standartizacijos departamentas, $1998.6 \mathrm{p}$.

8. A. Nyderis. Šlumos izoliacijos gaminiu gaisrinio pavojingumo ịvertinimas // Statyba ir architektūra. Konferencijos pranešimu medžiaga. 199704 9-11. Kaunas: Technologija, 1997, p. 182-188.

9. A. Nyderis. Pastatụ atitvaru su šilumos izoliacija gaisrinio pavojingumo bandymo metodas // Statyba ir architektūra. Konferencijos pranešimụ medžiaga. 1998 04 8-10. Kaunas: Technologija, 1998, p. 265-270.

10. Y. Hasemi, M. Yoshida, N. Yasui, W. J. Parker. Upward flame spread along a vertical solid for transient local heat release rate. Fire Safety Science-Proceedings of the Fourth International Symposium / International Association for Fire Safety Science, 1994, p. 385-396.

11. M. A. Delichatsios and M. M. Delichatsios. Upward flame spread and critical conditions for PE/PVC cables in a Tray configuration. Fire Safety Science-Proceedings of the Fourth International Symposium / International Association for Fire Safety Science, 1994, p. 421-432.

12. Ch. Qian and K. Saito. An empirical model for upward flame spread over vertical flat and corner walls. Fire Safety Science-Proceedings of the Fifth International Symposium / International Association for Fire Safety Science, 1997, p. 285-296.

13. C. L. Beyler, S. P. Hunt, N. Iqbal and F. W. Williams. A computer model of upward flame spread on vertical Surfaces. Fire Safety Science-Proceedings of the Fifth International Symposium / International Association for Fire Safety Science, 1997, p. 297-308.

14. M. Kokkala, D. Baroudi and W. J. Parker. Upward flame spread on wooden surface products: experiments and numerical modeling. Fire Safety Science-Proceedings of the Fifth International Symposium / International Association for Fire Safety Science, 1997, p. 309-320.

15. V. Babrauskas. Modern Test Methods for Flammability. NISTR 4326. US Department of Commerce. National Institute of Standards and Technology, 1990.24 p.

16. Development of the Single Burning Item Test. Results of the SBI Round Robin tests / VTT. Technical Research Centre of Finland, 1997. 67 p.

17. CEN/TC 127 Fire Safety in Building document N1320. Nomination for new adhoc groups. Secretariat of CEN/ TC $127,1998.4 \mathrm{p}$.

18. CEN/TC 127 Fire Safety in Building document N1318. Draft report of the 32 meeting to consider fire resistance held on 30/31 March 1998. Secretariat of CEN/TC 127, 1998.16p.
Iteikta 19990120

\section{THE ESTIMATION PROBLEMS OF THE FIRE HAZARD} FOR VERTICALLY ORIENTED BUILDING PRODUCTS

\section{A. Nyderis \\ Su m m a r y}

The Directive of new approach $89 / 106 / \mathrm{EEC}$, which was prepared by Directorate General of the European Commission (DG III), defines the guidelines for development of fire protection in building construction. Six main directions for development of fire protection are defined in this Directive as well.

Solid materials are most numerous among building products. Therefore a brief analysis of combustion process of these materials is presented in this article. F.Williams developed the theoretical principles of combustion. Phase transitions in the zone of combustion are analyzed in the theory. Formulas 1-4 describe this process. The process of combustion of solid materials is heterogeneous; therefore the model of pyrolysis is presented by 5 formulas.

An intricate energy exchange takes place in real fires. The heat is being transferred in different ways. The most acceptable description of heat transfer is by means of radiation. Description of this process is presented in formulas 6-7. The heat transfer by means of radiation can be modelled and used for environment testing.

The combustibility of building products can be examined by means of reaction of fire tests. In recent years tests for different building products were carried out according to ISO 5657 test methodology in the Fire Research Centre. Test results indicate that the time to sustained surface ignition for building products is inversely proportional to heat flux. This logarithmic dependence is presented in 8 formulas. Establishment of parameters of this logarithmic flow for different building products can prove this. This work was carried out during the process of verification of this hypothesis.

Analysis of fire testing practice of vertically oriented building products in different countries shows that harmonized fire test methods for these products do not exist. Most of these test methods are based on presumption that the flame spread is possible only inside the building not considering the behaviour of facade in fire.

The main idea of fire test method for element of vertically oriented building construction together with the principal scheme of test equipment are presented in the article as well.

Further development of this idea leads to five questions, which should be answered to solve the problem. After the completion of this task and analysis of test results, all the information is to be submitted for further consideration.

Albertas NYDERIS. MSc (fire safety and engineering). Fire Research Centre. Švitrigailos 18,2600 Vilnius.

Head of the Centre. Training courses at Danish Institute of Fire Technology, Technical Research Centre of Finland (VTT), Finish Accreditation Service (FINAS), Polish Centre for Testing and Certification (PCBC). Author of 7 research works, co-author of 4 Lithuanian standards. 